\title{
A PEPTIDE FRAGMENT OF PEPSIN CONTAINING METHIONINE
}

\author{
V. I. Vasenev, Yu. S. Kuznetsov, and V. M. Stepanov
}

Khimiya Prirodnykh Soedinenii, Vol. 5, No. 6, pp. 609-610, 1969

UDC 547.964

The determination of the sequence in which the peptides formed in the cyanogen bromide cleavage of pepsin [1] are connected in its molecule is an important step in the determination of the structure of the protein. For this purpose it is necessary to know the sequence of the amino acids surrounding the methionine residues.

In order to obtain methionine peptides, a pepsin hydrolysate from denatured pepsin $\left(\mathrm{pH} 5.0,37^{\circ} \mathrm{C}, 24 \mathrm{hr}\right)[2]$ was separated succesively on Sephadex G-50, Biogel P-2, and Dowex $1 \times 2$ and Dowex $50 \times 2$ ion-exchange resins. After further purification by chromatography and high-voltage paper electrophoresis, a heptapeptide of the following composition was isolated: $\operatorname{Ty}_{1}(0.151 \mu \mathrm{M}), \mathrm{Gly}_{2}(0.355 \mu \mathrm{M})$, $\operatorname{Ser}_{1}(0.182 \mu \mathrm{M})$. Thr $\mathrm{T}_{2}(0.299 \mu \mathrm{M})$, and Met $\mathrm{T}_{1}(0.134 \mu \mathrm{M})$.

It was shown by dinitrophenylation that the tyrosine occupies the $\mathrm{N}$-terminal position in the peptide. Cleavage with leucine aminopeptidase permitted the determination of the N-terminal sequence: Tyr-Gly-Thr-. As was shown by hydrazinolysis $=3$ ], the $\mathrm{C}$-terminal amino acid is methionine. This is confirmed by the fact that the action of cyanogen bromide does not lead to the cleavage of the peptide. Hydrolysis with carboxypeptidase $\mathrm{A}$ showed that at the $\mathrm{C}$-end the peptide has the sequence Gly-(Thr, Met). Consequently, the peptide is ascribed the structure Tyr-Gly-Thr-Ser-Gly-Thr-Met.

The sequence that we have found partly coincides with the sequence of amino acids close to one of the four methionine residues of pepsin [4]:

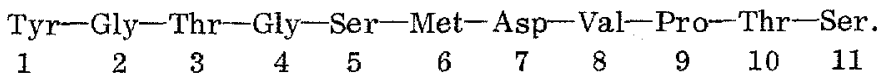

The difference that exists is still difficult to explain, since Tang and Hartley [4] gave no experimental data.

The sequence of amino acids 7-11 corresponds to the $\mathrm{N}$-terminal part of the C-terminal fragment of pepsin studied previously [1]. We assume that the heptapeptide that we have studied precedes the C-terminal fragment B-1 in the polypeptide chain of pepsin.

\section{R E F ERENCES}

1. V. I. Ostoslavskaya, I. B. Pugacheva, E. A. Vakhitova, V. F. Krivtsov, G. L. Muratova, E. D. Levin, and V. M. Stepanov, Biokhim., 33, 331, 1968.

2. Yu. S. Kuznetsov and V. M. Stepanov, Biokhim., 31, 623, 1966.

3. V. Braun and W. A. Schroeder, Arch. Bioch. Bioph., 118, 241-252, 1967.

4. J. Tang and B. S. Hartley, Atlas of Protein Sequence and Structure, 211, 1967-1968.

15 July 1969

Institute of the Chemistry of Natural Compounds AS USSR 